\title{
Effect of Parboiling and Storage Periods on Grain Quality Characters of G179 Rice Cultivar
}

\author{
Medhat A.E.El- Dalil ${ }^{1}$
}

\begin{abstract}
This study was conducted at Rice Technology and Training Center (RTTC) Alexandria during 2014/2015 seasons. The main objectives of present study were to determine the effect of parboiling and storage periods on grain quality characters of Giza 179 rice cultivar during 2014 and 2015 rice growing seasons. Fresh harvested paddy was adjusted to $14 \%$ moisture content and then parboiled to evaluate the effect of parboiling. After parboiling the samples were stored for three storage period, i.e. 3, 6 and 9 months to investigate the effect of storage conditions on the parboiled rice. The results indicated significant differences for most studied characters during both study seasons. Storage for nine months gave the highest values for hulling $\%$, milling $\%$, broken \%, water uptake, cooking time, protein amylase and elongation during both study seasons. While, the highest values for 1000 grain weight, hardness, gel consistency and gelatinization temperature were noticed for control during both seasons.
\end{abstract} storage

Key words: Oryza sativa L.; Grain quality; parboiling;

\section{INTRODUCTION}

Egypt produces yearly about 6 million tons of paddy. This production is seasonal while consumption is continuous throughout the year. Suitable storage conditions must be provided for the paddy after harvest until it is needed for consumption. During storage Physico-chemical properties of paddy keep changing and degree of changes vary depending on storage condition prevail.

Giza 179 is newly released rice cultivar in Egypt. This cultivar possess high yielding ability besides resistance to blast disease, the most distractive disease attacks rice in Egypt, tolerant to some abaiotic stress (salinity and drought). This cultivar however has a defect in its milling characters. The broken percentage reaches more than $10 \%$ which reduces commercial value. Effort has been done to overcome this problem through breeding program and/or some agronomy practices. One of these practices is parboiling.

It is though that parboiling come into use merely to facilitate the removal of the husk from paddy and to minimize its breakage during milling. From the nutritional point of view, parboiling fills the void spaces and cements the cracks inside the endosperm making the grain hoarder and minimizing internal fissuring and thereby breakage during milling (corren et al.,2006). The market value of milled rice as a product depends largely on physical qualities after the processing. The milling of parboiled rice presents has difficulty because the loss of nutrient during polishing at a less rapid rate than in the case if raw rice. It should be noted, however, that parboiled rice will also suffer loss of nutrient if the polishing is carried out too far.

The important of parboiling rice has pronounced in many developing countries as a means for reducing post harvest losses. Parboiling is a hydrothermic process in which rough rice is steeped in water, steamed and dried. The main change brought by this treatment to rice is gelatinization of starch and disintegration of the protein bodies in the endosperm, which expand and fill the interanular spaces enchased by polygonal starch granules. This process imports hardness to the rice and then parboiled rice exhibits less breakage during milling.

Accordingly, the present study aimed to study the effect of parboiling on grain quality character especially milling character and the effect of storage period of parboiled grain on the Physico-chemical characters of Giza 179 cultivar.

\section{MATERIALS AND METHODS}

Certified seeds of Giza 179 cultivar were provided by the Rice Research Section, Field Crops Research Institute, Agriculture Research center, Sakha, Kafr El Sheikh, Egypt during 2014 and 2015 rice growing seasons. The grain quality characters and parboling process were done and tested at the laboratories Rice Technology Training Center (RTTC) Alexandria Egypt.

The paddy was mechanically cleaned and impurities were removed based on shape, size and specific weight and then packed in jut sacks and then parboiled paddy were stored immediately after parboiling at room temperature $\left(15 c^{0}-27 c^{0}\right)$ and $\mathrm{RH} \quad 63 \%: 84 \%$ for 9 months such conditions. The storage periods were 3,6 and 9 months.

\section{Parboiling process using steam (German method)}

A control sample (Zero time storage) was analyzed after the processing and dried (13.5\%) Schule process. The peculiarity of this system is that steam is not directly applied to the paddy but is only used to heat the

${ }^{1}$ Rice Technology Training Center (RTTC), Field Crops 
water. The paddy is put into a pressure tank and is first soaked for about 120 minutes in medium temperature water kept in circulation. When the rice has reached the temperature of the soaking water the water supply off and Hydrostatic pressure of 4 to $6 \mathrm{~kg} / \mathrm{cm}$ is applied by admitting compressed air. The second heating or cooking period starts by lowering and readmitting water heated to a very high temperature to ensure that the starch gelatinizes completely. The water is then drained away and the paddy with a moisture content of about to 30 - 35 percent (w.b.) (Kimura,et al,.1976 and Bhattachorya 1985) drying is continued until a moisture content of 13 percent is reached at room temperature.

\section{Studied characters:}

1- moisture content

The moisture content of paddy sample was determined using a sample of 20 grams whole paddy grains after being placed in forced convection oven set (model ws-3), at $130 \mathrm{c}$ for 16 hours (Mathews 1962

2- Head rice yield

Paddy $(250 \mathrm{~g})$ husked through a satake roll huller (Model HU35 A.Japan) after that the kernels were Polished using a Satake rice polisher (Model TM05, Japan).

3- Thousand grain weight

For the one thousand grain test, the granometer Satake grain counter (Model Ky-130, Japan) was used to randomly count the required numbers. The value as a average of five replicates were recorded.

4- Dimensions

TheDimensions of paddy grains (length,thickness, and width) were measured by Satake shep tester
(Model MK-200, Japan ) with range $0-20 \mathrm{~m} \mathrm{~m}$ and accuracy $0.01 \mathrm{~m} \mathrm{~m}$.(khush et al .,1979).

5- Hardness

Grain hardness was measured using grain hardness tester for each rice sample 10 grains were tested. (Islam et al 2001 )

6- Amylose

Amylose content was estimated by the simplify procedure by Juliano, 1971

7- Gel consistency

Gel consistency was determined by procedure described by ( Cagampang et al.,1973 )

8- Gelatinization temperature

Gelatinization temperature was recorded according to (little et al., 1958).

9- Protein

Protein content was determined for brown rice, according to standard Micro-Kjeldahl method. Then the estimated nitrogen content was multiplied by a factor of 5.95 to estimate the crude protein content.

10-Water up take

Water up take at $77 \mathrm{c}$ was determined for milled rice sample as described by (Simpson et al.,1965).

11-Elongation

Elongation ratio was calculated according to (Azeez and Shafi.,!966)

The samples were arranged in a randomized complete block design with $r$ replicates. Analysis of variance were estimated according to Gomez and Gomez (1984) using SAS program,version 8.0.

\section{RESULTS AND DISCUSSION}

\begin{tabular}{|c|c|c|c|c|}
\hline \multirow[b]{2}{*}{ character } & \multicolumn{2}{|c|}{ Before parboiling } & \multicolumn{2}{|c|}{ After parboiling (control) } \\
\hline & 2014 & 2015 & 2014 & 2015 \\
\hline Hulling \% & 79.67 & 79.11 & 79.25 & 79.22 \\
\hline Milling \% & 69.79 & 69.88 & 70.05 & 70.00 \\
\hline Broken \% & 7.91 & 7.95 & 1.88 & 1.84 \\
\hline Grain length (m.m) & 5.66 & 5.78 & 5.73 & 5.80 \\
\hline Grain width (m.m) & 2.72 & 2.81 & 2.71 & 2.82 \\
\hline Grain thickness (m.m) & 1.99 & 2.17 & 2.18 & 2.22 \\
\hline Grain shape $(\mathrm{L} / \mathrm{W})$ & 2.08 & 2.05 & 2.12 & 2.06 \\
\hline 1000 grain $(\mathrm{gm})$ & 22.84 & 22.98 & 22.87 & 23.00 \\
\hline Hardness $(\mathrm{Kg} / \mathrm{cm})$ & 5.22 & 4.99 & 9.13 & 9.20 \\
\hline water up take (ml/100gm) & 460.1 & 466.2 & 476.33 & 475.67 \\
\hline cooking time (min) & 20.00 & 21.67 & 23.00 & 23.07 \\
\hline Protein content $(\%)$ & 8.63 & 8.38 & 8.91 & 8.80 \\
\hline Amylose content (\%) & 19.09 & 19.14 & 19.14 & 19.15 \\
\hline Elongation (\%) & 57.12 & 54.87 & 58.71 & 55.42 \\
\hline gel consistency (G.c)(mm) & 92.88 & 90.98 & 91.52 & 91.84 \\
\hline Gelatinization temperature (G.T.) Spreading & 4.89 & 4.73 & 4.82 & 4.78 \\
\hline Clearing & 4.19 & 4.01 & 4.59 & 4.62 \\
\hline
\end{tabular}




\section{The effect of storage period subjected to parboiling}

Table (1) showed that milling characters were significantly effected by parboiling and storage periods during both seasons. Data indicated that the highest values for hulling \% (79.25 and 79.22\%) were noticed with control in 2014 and 2015 seasons respectively. Moreover, The highest values for milling \% (70.12 and $70.06 \%$ ) were recognized with storage for 9 months in 2014 and 2015 seasons respectively. Furthermore, data declared that the highest broken \% in 2014 and 2015 seasons were 2.16 and $2.10 \%$ respectively. These results were in harmony with those reported by El Akary et.al.(1997).

Data in table (2) represent effect of parboiling and storage periods of Giza 179 rice cultivar during 2014 and 2015 seasons. Data in table 2, showed that storage periods doesn't effect on grain dimensions characters during both study seasons. These results were in harmony with Fofana et.al., 2011

Data in table (3) revealed significant differences between studied characters as effected by storage periods during both study seasons. The highest values for 1000 grain weight (22.87 and $23.00 \mathrm{gm})$ were noticed with control in 2014 and 2015 seasons, respectively This might be due to increase storage period the moisture content $\%$ decrease so $\%$ of 1000 grain weight grain weight. These results were in harmony with Islam et. al., 2001 and Bello et.al., 2006.

Moreover, data indicated that the highest values for hardness $(9.13$ and $9.20 \mathrm{~kg} / \mathrm{cm})$ were noticed with control in 2014 and 2015, respectively. This results were in agreement with Juliano 1985, Banjong 1986, and bocevska et.al., 2009.

Furthermore, data in table (3) revealed that increasing storge perieds significantly icreased cooking time and water up take during both study seasons. The highest values for both characters were noticed by storage for 9 month during both study seasons. The highest values for cooking time were 23.84 and $23.800 \mathrm{~min}$ while values for water up take were 485.33 and $58 \mathrm{ml} / 100 \mathrm{gm}$ milld rice grains in 2014 and 2015 respectivety. These results were in agreement with Singh et.al. 2005.

In addition data in table (4) revealed that storage for 9 months significantly increased portein content \%, Amylose \% and Elongations \% during both study seasons. These results were in harmony with Elakary et.al., 1997. The highest values for protein \% were 9.02 and $8.99 \%$ in 2014 and 2015 seasons respctively. Moreover the highest values for Amylose \% were 20.03 and $19.92 \%$ while for elongation the highest values were 59.37 and $59.40 \%$ in 2014 and 2015 seasons respctively.These results were in harmony with Hermansson and Svegmork 1996.and Juliano., et. al.,1981.

Table 1. Effect of storage periods and parboiled grains of Giza 179 rice cultivar on hulling, milling and Broken characteristics daring 2014 and 2015 seasons

\begin{tabular}{cccccccc}
\hline \multirow{2}{*}{ Treatment } & \multicolumn{2}{c}{ Hulling (\%) } & \multicolumn{2}{c}{ Milling (\%) } & \multicolumn{2}{c}{ Broken (\%) } \\
\cline { 2 - 7 } & $\mathbf{2 0 1 4}$ & $\mathbf{2 0 1 5}$ & $\mathbf{2 0 1 4}$ & $\mathbf{2 0 1 5}$ & $\mathbf{2 0 1 4}$ & $\mathbf{2 0 1 5}$ \\
\hline Storage period & & & & & & \\
\hline Control & 79.25 & 79.22 & 70.05 & 70.00 & 1.88 & 1.84 \\
3 & 79.41 & 79.38 & 69.90 & 69.83 & 1.90 & 1.85 \\
6 & 79.59 & 79.66 & 69.97 & 69.90 & 2.02 & 2.07 \\
9 & 80.06 & 80.13 & 70.12 & 70.06 & 2.16 & 2.10 \\
L.S.D. & 0.151 & 0.127 & 0.051 & 0.032 & 0.102 & 0.115 \\
\hline
\end{tabular}

Table 2. Effect of storage periods and parboiled grains of Giza 179 rice cultivar on grain dimensions characteristics during 2014 and 2015 seasons

\begin{tabular}{|c|c|c|c|c|c|c|c|c|c|}
\hline \multirow[t]{2}{*}{ Treatment } & \multirow[b]{2}{*}{ Storage period } & \multicolumn{2}{|c|}{$\begin{array}{c}\text { Grain length } \\
(\mathrm{mm})\end{array}$} & \multicolumn{2}{|c|}{$\begin{array}{l}\text { Grain width } \\
(\mathrm{mm})\end{array}$} & \multicolumn{2}{|c|}{ Grain thickness (mm } & \multicolumn{2}{|c|}{$\begin{array}{c}\text { Grain shape } \\
(\mathrm{L} / \mathrm{W})\end{array}$} \\
\hline & & 2014 & 2015 & 2014 & 2015 & 2014 & 2015 & 2014 & 2015 \\
\hline & Control & 5.73 & 5.80 & 2.71 & 2.82 & 2.18 & 2.22 & 2.12 & 2.06 \\
\hline & 3 & 5.74 & 5.70 & 2.78 & 2.70 & 2.21 & 2.19 & 2.06 & 2.11 \\
\hline & 6 & 5.81 & 5.74 & 2.84 & 2.82 & 2.22 & 2.27 & 2.04 & 2.03 \\
\hline & 9 & 5.76 & 5.79 & 2.88 & 2.83 & 2.25 & 2.29 & 2.00 & 2.04 \\
\hline & L.S.D. & n.s & n.s & n.s & n.s & n.s & n.s & n.s & n.s \\
\hline
\end{tabular}


Table 3. Effect of storage periods and parboiled grains of Giza 179 rice cultivar on 1000 grain, hardness, water up take and cooking time characteristics during 2014 and 2015 seasons

\begin{tabular}{ccccccccc}
\hline & \multicolumn{2}{c}{$\begin{array}{c}\text { 1000 grain } \\
\text { Trm) }\end{array}$} & \multicolumn{2}{c}{$\begin{array}{c}\text { Hardness } \\
(\mathbf{K g} / \mathbf{c m})\end{array}$} & \multicolumn{2}{c}{$\begin{array}{c}\text { water up take } \\
(\mathbf{m l} / \mathbf{1 0 0 g m})\end{array}$} & \multicolumn{2}{c}{$\begin{array}{c}\text { cooking time } \\
(\mathbf{m i n})\end{array}$} \\
\cline { 2 - 9 } Storage period & $\mathbf{2 0 1 4}$ & $\mathbf{2 0 1 5}$ & $\mathbf{2 0 1 4}$ & $\mathbf{2 0 1 5}$ & $\mathbf{2 0 1 4}$ & $\mathbf{2 0 1 5}$ & $\mathbf{2 0 1 4}$ & $\mathbf{2 0 1 5}$ \\
\hline Control & 22.87 & 23.00 & 9.13 & 9.20 & 476.33 & 475.67 & 23.00 & 23.07 \\
3 & 22.84 & 22.69 & 8.82 & 9.00 & 479.67 & 479.67 & 23.17 & 23.14 \\
6 & 22.65 & 22.66 & 9.00 & 9.06 & 483.00 & 482.33 & 23.48 & 23.50 \\
9 & 22.44 & 22.50 & 8.80 & 8.82 & 485.33 & 485.00 & 23.84 & 23.80 \\
L.S.D. & 0.030 & 0.0112 & 0.153 & 0.0122 & 1.356 & 2.725 & 0.164 & 0.055 \\
\hline
\end{tabular}

Table 4. Effect of storage periods and parboiled grains of Giza 179 rice cultivar on grain Protein, Amylose and Elongation characteristics during 2014 and 2015 seasons

\begin{tabular}{|c|c|c|c|c|c|c|c|}
\hline \multirow[t]{2}{*}{ Treatment } & & \multicolumn{2}{|c|}{ Protein content $(\%)$} & \multicolumn{2}{|c|}{ Amylosecontent (\%) } & \multicolumn{2}{|c|}{ Elongation (\%) } \\
\hline & & 2014 & 2015 & 2014 & 2015 & 2014 & 2015 \\
\hline \multicolumn{8}{|c|}{ Storage period } \\
\hline & Control & 8.91 & 8.80 & 19.14 & 19.15 & 58.71 & 55.42 \\
\hline & 3 & 8.88 & 8.74 & 19.62 & 19.60 & 58.53 & 58.92 \\
\hline & 6 & 8.86 & 8.76 & 19.86 & 19.92 & 59.13 & 59.02 \\
\hline & 9 & 9.02 & 8.99 & 20.03 & 20.82 & 59.37 & 59.40 \\
\hline & L.S.D. & 0.015 & 0.020 & 0.155 & 0.432 & 0.172 & 0.351 \\
\hline
\end{tabular}

Table 5. Effect of storage periods and parboiled grains of Giza 179 rice cultivar on grain gel consistency and gelatinization temperature characteristics during 2014 and 2015 seasons

\begin{tabular}{|c|c|c|c|c|c|c|c|}
\hline \multirow[t]{3}{*}{ Treatment } & \multirow[b]{3}{*}{ Storage period } & \multirow{2}{*}{\multicolumn{2}{|c|}{$\begin{array}{c}\text { gel consistency (G.c) } \\
(\mathrm{mm})\end{array}$}} & \multicolumn{4}{|c|}{ gelatinization temperature (G.t) } \\
\hline & & & & \multicolumn{2}{|c|}{ spreading } & \multicolumn{2}{|c|}{ clearing } \\
\hline & & 2014 & 2015 & 2014 & 2015 & 2014 & 2015 \\
\hline & Control & 91.52 & 91.84 & 4.82 & 4.78 & 4.59 & 4.62 \\
\hline & 3 & 91.02 & 90.98 & 4.73 & 4.64 & 4.45 & 4.43 \\
\hline & 6 & 90.46 & 90.40 & 4.54 & 4.55 & 4.40 & 4.39 \\
\hline & 9 & 90.06 & 90.03 & 4.06 & 4.04 & 4.23 & 4.26 \\
\hline & L.S.D. & 0.339 & 0.481 & 0.082 & 0.134 & 0.042 & 0.033 \\
\hline
\end{tabular}

Further data in table (5) indicated that Gel consistency and gelatinization temperature showed the highest values with control during 2014 and 2015 seasons. The highest values for Gel consistency were 91.52 and $91.4 \mathrm{~mm}$ in 2014 and 2015 seasons respectively. These results were in harmony with Cagampang et.al. 1973. Moreover the highest values for Spreading 4.82 and 4.78 while the highest values for Clearing were 4.59 and 4.62 in 2014 and 2015 seasons respectively. These results were in agreement with Yehand li., 1996 and Wang and Sastry 1997.

\section{CONCLUSION}

Finally, it can be concluded that grain quality characteristics of Giza 179 cultivar were affected by parboiling, and the parboiled grain were significantly affected by storage period. Nine months' storage gives the highest values for hulling $\%$, milling $\%$, broken $\%$, water uptake, cooking time, protein amylase and elongation during both study seasons. While, the highest values for 1000 grain weight, hardness, gel consistency and gelatinization temperature were noticed with control during both seasons.

\section{REFERENCES}

A garwal, N.S. Parboiling of rice in india . Bull Grain Technol., 1 (3): 55-60 1963.

An,H., J.King. 2007.Thermal characteristics of Chemically heated rice starch and rice flours. Journal of food Science . 72(1).CO 84-CO88.

Azeez, M.A. and M.Shafi. 1966. Quality in Rice. Department of Agric, West Pakistan Technology Bulletin. No. 13 pp. 50 .

Banjong, K. 1968. Alocal extrusion test evolution cooked rice texture. Thesis No. AE-86-20 Asian Institiute of Technology. Pathumthoni. Thailand.

Bello,M., R.Baeza, and M.P. Tolba.2006. Quality characteristics of milled rice affected by hydrothermal. Journal of food engineering 72:124-133

Bhattacharya,K.R. and P.V.Subba Roo. 1996 a. Processing conditions and milling yield in Parboiling of rice Journal of agricultural food chemistry,14:473-475. 
Bhattacharya,K.R. and P.V. Subba Roo. 1996 b. Effect of processing conditions on quality of parboiled of rice. Journal of agricultural food chemistry, 14:476-479.A

Bhattacharya, K.R. 1985. Parboiling of rice. In: Rice chemistry and technology ed by B.O.Juliano. American Association of cereal chemists . Ine.St Paul . Minmesota pp:289-348.A

Bocevska,M., I.Aldabas, D.Andreeevska and V.Llieva. 2009. Gelatinization behavior of grains and flour in relation to physio- chemical properties of milled rice (Oryza Sativa L.). Journal of Food Quality, 32 (1) - 108124.

,Breckenridge,C. 1979 .Rice grain evaluation in siri lanka. Page 175 in proc.wkshp.chem.A spects of rice grain quality Int. Rice Research for posting charcteristics starch gelatinization temperature . Staerke 37:40.

Cagampang,G.B., C.M. Perez and b.O. Juliano. 1973 . A gel consistency test for eating on quality of A parboiled Of rice .J.sci. food Agric.24:1589A

Correa PC.Shwany da F .Silva, C.Jaren, PC.J Al-fonso and I.Arana . 2006 . physical and mecanical properties in rice processing .Journal of food engineering 79:137-142.

Gomez,K.A., and A.A.Gomez. 1984. Statistical procedures for agricultural Research. An International Rice Research Institural Book. John Willy and sons Inc.New York.comparison of important varieties local with new varieties adopted in Benin. Food control 22(12).18211825.

Fofana,M., J.B.Manful, I.Yaou, J.Dossou and R.Bleoussi. 2011. Rice grain quality A

Hermansson.M. and K.Svegmark. 1996 .Developments in the understanding of starch funclionality. Trends food Science and Technology.7.345-353

Islam,M.R., P.Roy, N.Shimizu. and T.Kimra. 2001. Quality evaluation of parboiled rice with physical properties. Food Science and Technology Research..7(1):57-63.

Islam,M.R., P.Roy ., N.Shimizu and T.Kimra. 2002. Effect of processing conditions on physical properties of parboiled rice .Food Science and Technology Research.8(2):106-112

Juliano,B.O.,1971. A simplified assay for milled-rice amylose. Cereal Sci. tody 16:334.

Juliano,B.O.,1985. International Survey of rice grain quality In:B.O.Juliano (ed) chemical aspects of rice grain quality.IRRI. Los Banos. Philippines. Pp.81-82.

Juliano,B.O., C.M.Perez, A.B.Blakeney, C.Breckeridge, D.T.Castilo, N.Kongseree and D.Webb. 1981.

International cooperation testing on amylose content of milled ricestarke.33.157-162.

Khush,g.S., C.M.Paule and N.M.De la cruz.1979. Rice grain quality evalution and improvement in proceedings of workshop on chimical aspects of rice grain quality pp 2131. Manila philippines .International Rice Research Institural.
Little, R.r., G.B.Hilder and e.H.Dason. 1958. Differential effect of dilute alkali on 25 varities of milled white rice. Cereal Chem.35-111.

Marchezan, E. 1991.raos inteiros em arroz (whole rice kernels in rice). Lavoora arrozeira porio alegre, Brazil 44:3-8.

Mathews,j. 1962 The accuracy of measurment of brown changes in moisture content of cereal by typical oven methods. Journal Agriulture Engineering Research. 7(3):185-191 .

Magdy ,O.E., E.A.Mohamed, M.Y.Mohamed, A.K.Hassan, F.F.Mahmoud and M.M.Abdel Salam.1997 .The third alexandria onference on Food Sciences and Technologey pp.46-66.

Reyes,V.g., J.R. and V.K.Jindal. 1990. Sample back extrusion test for meauring texture of cooked rice. Journal ofFood quality 13(2):109-118.

Sareepuang,K.,S.Siriamornpun, L.Wiset and Meeso.2008. Effect of soking temperature on physcal,chimical and cooking properties of parboled fragrment rice. World Journal of Agriulture Sciencees 4(4):109-115 .Issn18173017 .

Simpson, J.E., C.R.Adair, G.O.Kohler, E.H.Dawson, H.J.Deobald, E.B.Kester, J.T.Hogan, O.M.Batcher and J.V. Halick. 1965. Quality evaluation studies of foreign and domestic rices, pp. 186. U.S. Dept. Agric. Res. Serv. Tech. Bull. 1331.

Singh,N., L.Kaur, N.Singh Sodhi and Singh K.Ssekhon. 2005. Physichemical cooking and textural properties of milled rice different Indian rice cultivars. Fod chemistry.89(2)253-259.

Steff,J.F.Singel and G.e. Miller. 1980. Harvest,drying and storage of rough rice in rice production ad utillization luh.b.S (Ed.)AVI publisher company Inc.West port,connecticnt,United States of America pp1-350.

Kimura,T., J. Y.Matsuda and T.Yoshida. 1976. Basicstudies on arboiled rice (3): Effect of proccessing conditions on properties of parboiled rice. Journal of Japanese socity of Agricultural Machinery. (38):379-383.

Velupillai,L., LR.Verma and M.C.M.Tsang. 1989. Process for parboilng rice United States patent No:4.810-511.

Wang,W.c. and S.K.Sastry. 1997. Starch gelatinization in ohmic heaing. Journl of Food engineering .34(3).225-242.

Wimberly,J.E. 1983. Parboiling In: Technical Hand Book for the paddy rice post harvest Industry in Developing countries pp.101-116.

Yeh,A.1. and J.y.Li. 1996. A continous measurement of rice starch during heating. Journl of Cereal Science.23.277283.Journl of Food engineering .34(3).225-242.

Zhout,T., K.Robards, S.Helluvell and C.Blonchard. 2002. A geing of stored rice chans in chemical and physical attributes. Journl of Food engineering .33. 65-78. 


\section{الملخص العربي \\ تأثير الظلى وفترات التخزين على جودة حبوب الأرز فى الصنف جيزة لو \\ مدحت عبد المنعم الدليل}

أجريت هذه الدر اسة فى مركز تدريب تكنولوجيــا الأرز معنوية فى العديد من الصفات المدروسة خــلال موســى

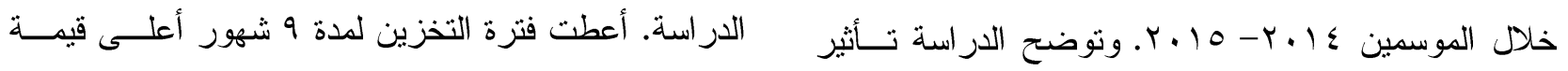

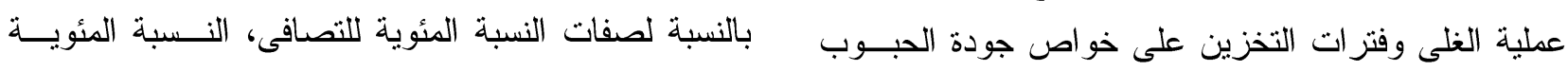

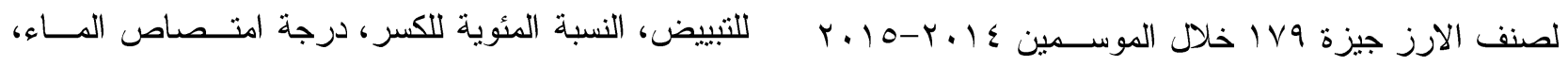



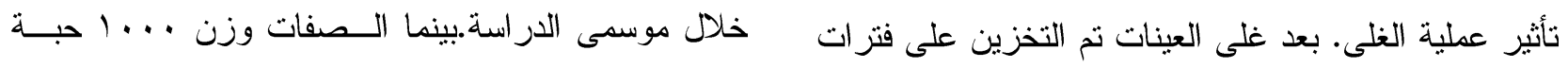

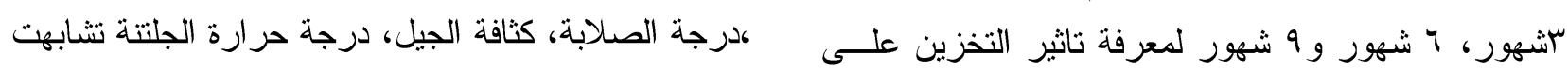
خو اص الأرز المغلى. أوضحت النتائج وجــود اختلافــات مع الكنتزول خلائل موسمى الدراسة. 